\title{
Application of HBM Theory (Health Belief Model) to Preventing Behavior of Hypertension Complications in Public Health Center Raas, Sumenep Regency
}

\author{
Hermanto $^{1}$, Katmini ${ }^{2}$ \\ ${ }^{1}$ Health Center Raas Sumenep \\ ${ }^{2}$ Strada Indonesian Institute of \\ Health Sciences \\ Email: \\ abdulazis@gmail.com
}

Received : October $4^{\text {nd }} 2021$

Accepted : October $15^{\text {rd } 2021}$

Published : November $27^{\text {th }} 2021$

\begin{abstract}
Hypertension is a non-communicable disease that can become a big and serious problem because of the high prevalence of hypertension and tends to increase. The purpose of this study is to analyzethe effect of perception, motivation and belief in the HBM Theory (Health Belief Model) on the behavior of preventing hypertension complications at the Raas Health Center, Sumenep Regency. The design of this research is an observational quantitative research with a cross sectional approach with the focus of the research being directed at analyzingthe effect of perception, motivation and belief in the HBM Theory (Health Belief Model) on the behavior of preventing hypertension complications at the Raas Health Center, Sumenep Regency. The total population is 160 respondents and a sample of 114 respondents is taken by using Simple Random Sampling technique. The findings showed that almost half of the respondents had a sufficient category perception as many as 47 respondents $(41 \%)$. Almost half of the respondents have a moderate category of motivation as many as 46 respondents $(40 \%)$. Almost half of the respondents have confidence in the medium category as many as 47 respondents (41\%). Most of the respondents have behavior in the less category as many as 84 respondents $(74 \%)$. Based on the results of the analysis Based on the results of the Multiple Linear Regression analysis showed that with a p-value of $0.000<0,05$, then $\mathrm{H} 1$ is accepted, so it can be concluded that there is a simultaneous influence of perception, motivation and belief on the behavior of preventing hypertension complications at the Raas Health Center, Sumenep Regency with a magnitude of $78.1 \%$. It is hoped that hypertensive patients can obediently consume drugs given by health workers, which drugs should be consumed until they run out according to schedule and routinely control health facilities used previously.
\end{abstract}

Keywords: Health belief model, hypertension \& behavior

Copyright (C) 2021 IIK STRADA Indonesia All right reserved.

This is an open-acces article distributed under the terms of the Creative Commons AttributionShareAlike 4.0 International License. 


\section{INTRODUCTION}

Hypertension is a non-communicable disease that can become a big and serious problem because of the high prevalence of hypertension and tends to increase. In 2018 there was an increase in the prevalence of hypertension based on interviews (whether diagnosed by health workers and taking hypertension medication) from $7.6 \%$ in 2012 to 9.5 percent (Riskesdas, 2018).

The prevalence of hypertension mostly occurs in the elderly group, however, it turns out that the prevalence of hypertension in the productive age group tends to increase from year to year. According to the Ministry of Health of the Republic of Indonesia (2017) based on the results of the 2012 Basic Health Research (Riskesdas), most cases of hypertension in the community have not been diagnosed. This can be seen from the results of measuring blood pressure at the age of 18 years and over, it is found that the prevalence of hypertension in Indonesia is $31.7 \%$, where only $7.2 \%$ of the population already knows they have hypertension. And $76 \%$ of hypertension cases in the community have not been diagnosed or the community does not know that they suffer from hypertension.

The prevalence of hypertension in Sumenep Regency in 2014 was 6.6\%, in 2015 it was $7.29 \%$ and in 2016 it was $5.78 \%$. Whereas in 2017 based on reports from the puskesmas the number of hypertension sufferers in Sumenep was 21,731 cases, in 2018 there were 20,516 cases and in 2019 there were 36,827 cases.

There are several factors that can increase a person's risk of suffering from hypertension. According to Sigarlaki (2016) the triggering factors for hypertension can be divided into 2, namely factors that cannot be controlled (such as gender, genetics, and age) and factors that can be controlled (non-adherence to taking medication, lack of exercise, smoking, consumption of salt and excess fat). ).

This condition causes hypertension in the community as a silent killer or the silent killer, because hypertension generally occurs without any symptoms or is asymptomatic. Hypertension develops slowly, but is potentially very dangerous because it is a major risk factor for the development of heart disease and stroke (Dalimarta et al., 2013).

Because hypertension is a silent killer, the only way is to prevent and control hypertension. Efforts to prevent and control hypertension must begin by increasing public awareness and making changes to a healthier lifestyle. To understand and practice the right lifestyle and avoid disease, individuals and society need to learn proper behavior (Miller, 2014). In this case, the health belief model (HBM) is the first theory in the field of health related to health behavior. HBM can explain prevention behavior and individual response to disease.

The perspective or perception of a person will affect behavior both consciously and unconsciously. As with the behavior of preventing the occurrence of complications of hypertension, it can be influenced by the perception that this disease is not dangerous and the therapy is not important, many even believe in mystical treatment. Belief itself can influence behavior because basically someone will do something because someone believes it (Brenda, 2011).

Based on the above conditions, the authors are interested in researching the application of the HBM Theory (Health Belief Model) to the behavior of preventing hypertension complications at the Raas Health Center, Sumenep Regency.

\section{MATERIALS AND METHODS}

In this study, the researcher uses an observational quantitative design with a cross sectional approach, which is a study to study the dynamics of the correlation between risk factors and effects, by approaching, observing or collecting data all at once (point time approach), that is, each subject The study was observed only once and measurements were made on the status of the character or variable of the subject at the time of examination. This does not mean that all research subjects are observed at the same time (Soekidjo, 2012). This research will analyzethe effect of perception, motivation and belief in the HBM Theory (Health Belief Model) on the behavior of preventing hypertension complications at the Raas Health Center, Sumenep Regency. The total population is 160 respondents and a sample of 114 respondents is taken by using Simple Random Sampling technique. Data analysis using Linear Regression test. This research has conducted an ethical test with the number SK: 2300/KEPK/III/2021. 


\section{RESULT}

Table 1 Results of linear regression analysis the application of the HBM (Health Belief Model) theory to the behavior of preventing hypertension complications at the Raas Health Center, Sumenep Regency which was held on March 1-30, 2021 with a total of 114 respondents

\begin{tabular}{|c|c|c|c|c|c|}
\hline No & Variable & Sig & B & $R^{2}$ & Sig \\
\hline 1 & (Constant) & 0.002 & 1,119 & & \\
\cline { 1 - 4 } 2 & Perception & 0.008 & 0.920 & \multirow{2}{*}{0.781} & \multirow{2}{*}{0.000} \\
\cline { 1 - 3 } 3 & Motivation & 0.000 & 0.823 & & \\
\hline 4 & Trust & 0.002 & 0.638 & & \\
\hline
\end{tabular}

\section{Partial}

a. The Influence of Perception on Behavior

Based on the results of Linear Regression analysis shows that the p-value is $0.008<0.05$ then $\mathrm{H} 1$ is accepted so it is concluded that partially there is the effect of perception on the behavior of preventing the occurrence of hypertension complications at the Raas Health Center, Sumenep Regency.

b. The Effect of Motivation on Behavior

Based on the results of Linear Regression analysis shows that the p-value 0.000 $<0.05$ then $\mathrm{H} 0$ is rejected and $\mathrm{H} 1$ is accepted so it is concluded that partially there is the influence of motivation on the behavior of preventing complications of hypertension at the Raas Health Center, Sumenep Regency.

c. The Effect of Belief on Behavior

Based on the results of Linear Regression analysis shows that the p-value is $0.002<0.05$, then $\mathrm{H} 0$ is rejected and $\mathrm{H} 1$ is accepted, so it can be concluded that partially there is the influence of trust on behavior to prevent hypertension complications at Raas Public Health Center, Sumenep Regency

\section{Simultaneous}

Based on the results of Multiple Linear Regression analysis shows that with a pvalue of $0.000<0.05$ then $\mathrm{H} 1$ is accepted so it can be concluded that simultaneously there is the influence of perception, motivation and belief on the behavior of preventing the occurrence of complications of hypertension at the Raas Public Health Center, Sumenep Regency with a magnitude of $78.1 \%$.

\section{DISCUSSION}

\section{A. Perceptions of Behavioral Prevention of Complications of Hypertension at Raas Health Center, Sumenep Regency}

The results showed that almost half of the respondents had a sufficient category perception as many as 47 respondents (41\%). In addition, 41 respondents (36\%) have a perception of the kruang category. While a number of 26 respondents $(23 \%)$ have a good category perception.

According to Herri Zan Pieter (2015) perception relates to phenomena where the relationship between stimulus and experience is more complex than the phenomena that exist in sensation. The phenomenon of perception depends on higher-level processes.

Generally the term perception is used in the field of psychology. In terms of terminology as stated by Purwodarminta (2011), the notion of perception is a direct response from an absorption or process of someone knowing some things through sensing. Whereas in the big psychology dictionary, perception is defined as a process of observing a person's environment by using his senses so that he becomes aware of everything that is in his environment.

According to Ali and Asrori (2014) the notion of perception is "the process of individuals in interpreting, organizing and giving meaning to stimuli that come from the environment in which the individual is located which is the result of the learning process 
and experience." In terms of perception, there are two important elements, namely interpretation and organization. Interpretation is an effort to understand the individual to the information obtained. While organization is the process of managing certain information so that it has meaning.

Perception is a process that is learned through interaction with the surrounding environment. A person's perception arises from childhood through interaction with other humans. In line with this, Rakhmat (2012) defines the notion of perception as: "experience of objects, events or relationships obtained by inferring information and interpreting messages". This similarity of opinion can be seen from the meaning of inferring information and interpreting messages that are related to the process of giving meaning.

Eysenck in Asrori (2014) states that perception actually requires a learning process and experience. The results of the learning process and a person's interaction will provide experience for him to be able to compare the circumstances at hand.

According to researchers, perception is the process of receiving, differentiating, and giving meaning to the stimulus received by the senses, so that it can draw conclusions and interpret certain objects that it observes. The perception of a hypertensive patient in assessing his disease is quite diverse. Many patients think that hypertension is not a dangerous disease. Where respondents assess hypertension can heal by itself, so there is no need to worry about having to limit eating to having regular exercise. Because people generally have active activities by working, taking care of the house, taking care of children and other activities.

B. Motivation for Preventing Hypertension Complications at Raas Health Center, Sumenep Regency

The results showed that almost half of the respondents had a moderate category of motivation as many as 46 respondents (40\%). In addition, a number of 40 respondents $(35 \%)$ have a low motivation category. While a number of 28 respondents $(25 \%)$ have a high category of motivation.

Motivation is what causes and supports a person. According to Mashlow (2010) in Sunaryo (2013), individuals will be motivated to fulfill what needs are strongest in themselves at a certain time. If it is said that the emergence of a person's behavior at any given moment is determined by a need that has high power then it is important for every manager to have knowledge of the needs that are felt to be most important to their subordinates.

According to Ngalim Purwanto (2010) Motivation is everything that encourages someone to do something. Motivation is to provide a stimulus or impetus or an excitement to a person or group to want to work properly and enthusiastically. With its ability to achieve goals in an efficient and effective manner (Wijono D, 2012).

Meanwhile, Terry GR, provides a definition of motivation is the desire contained in an individual who stimulates him to take actions. According to Ishak Asep (2013) motivation is something basic, which encourages someone to work.

According to Sunarya in a psychology book for nursing (2013), motivation is the desire and need for individuals, to motivate the individual to fulfill their needs and direct behavior towards everything they aim at. According to Nancy Stevenson (2011) motivation is all verbal, physical, or psychological things that make someone do something in response. And according to Suwarno, sw (2010) motivation refers to the process of movement, including encouraging situations that arise from within the individual, behavior evoked by the situation and the ultimate goal of the movement or action. 
According to researchers, motivation will encourage someone to do something, where if someone has high motivation then that person will do everything possible so that his wishes can be achieved. Based on the results of the study, it was found that most of the respondents had moderate category motivation. However, there are still many respondents who have motivation in the low category, where this is due to the perception of the patient himself where the patient assumes that hypertension will heal itself without having to be treated and is not a dangerous disease so there is no need to worry about the disease.

\section{Belief in Prevention of Hypertension Complications at Raas Health Center, Sumenep Regency}

The results showed that almost half of the respondents had confidence in the medium category as many as 47 respondents (41\%). In addition, a number of 40 respondents $(35 \%)$ have a low confidence category. While a number of 27 respondents $(24 \%)$ have a high category of trust.

According to Mowen and Minor in Donni Juni (2017) Trust is all knowledge possessed by consumers and all conclusions made by consumers about objects, attributes and benefits. According to Rousseau et al in Donni Juni (2017) Trust is a psychological area which is a concern for accepting what is based on expectations of good behavior from others.

According to Maharani (2010), trust is the belief of one party in the reliability, durability, and integrity of the other party in the relationship and the belief that his actions are in the best interest and will produce positive results for the trusted party. Meanwhile, according to Pavlo in Donni Juni (2017) Trust is an assessment of one's relationship with other people who will carry out certain transactions in accordance with expectations in an environment full of uncertainty.

Hypertension occurs due to the accumulation of several hormones as a response to the instability of the blood circulation process in the body. This circulatory instability can be caused by extrinsic and intrinsic factors, namely factors originating from outside the body such as consumption of fatty foods, bad cholesterol, alcohol consumption and smoking, as well as psychological factors, while intrinsic factors are factors originating from within the body such as organ instability and stress. hormone secretion. High blood pressure is more common in elderly patients. This is because the aging process causes the work system of all organs to begin to decline (Wijaya, 2013).

According to researchers, trust is an expectation held by an individual when a word, promise, oral or written statement from an individual or another group can be realized. Where the things that are said by health workers can be believed by hypertensive patients and believe in all their recommendations to be done by patients. So that hypertensive patients want to do hypertension treatment such as limiting sodium consumption, limiting eating junk food and regularly taking medicine on their own accord without coercion. Based on the results of the study, it was found that many hypertensive patients had low confidence which was due to lack of knowledge of the benefits of treatment and also due to poor perceptions of health workers.

D. Behavior of Prevention of Complications of Hypertension at Raas Health Center, Sumenep Regency

The results showed that most of the respondents had behavior in the less category as many as 84 respondents (74\%). While a number of 30 respondents $(26 \%)$ have good behavior category.

Human behavior is the result of all kinds of experiences and human interactions with the environment that are manifested in the form of knowledge, attitudes and actions. In other words, behavior is a response / reaction of an individual to a stimulus that comes 
from outside or from within himself. This response can be passive (without action: think, think, act) or active (take action). In accordance with this limitation, behavior can be formulated as a form of experience and interaction of individuals with their environment, especially those concerning knowledge and attitudes about themselves. Active behavior can be seen, while passive behavior is invisible, such as knowledge, perception, or motivation. Some experts distinguish forms of behavior into three domains, namely knowledge, attitudes,

From a biological point of view, behavior is an activity or activity of the organism concerned, which can be observed directly or indirectly. Human behavior is a human activity itself (Notoadmodjo, 2013). American Encyclopedia, behavior is defined as an action-reaction of organisms to their environment. New behavior occurs when something is needed to cause a reaction, which is called a stimulus. It means that certain stimuli will produce certain reactions or behaviors (Notoadmodjo, 2013).

As quoted by Notoatmodjo (2013), behavior is an action or behavior of an organism that can be observed and even learned. In general, human behavior is essentially a process of individual interaction with the environment as a biological manifestation that he is a living being (Kusmiyati and Desminiarti, 2011). According to the author, what is called human behavior is an activity that arises because of a stimulus and response and can be observed directly or indirectly.

The process of forming or changing behavior can be influenced by several factors, both internal and external to the individual. Aspects within the individual that are very influential in changing behavior are perceptions, motivations and emotions. Perception is observation which is a combination of sight, hearing, smell and past experiences. Motivation is an impulse to act to satisfy a need. The impetus in motivation is manifested in the form of action (Sarwono, 2013).

According to researchers, behavior is a person's response or reaction to external stimuli. Behavior is an action or activity of the human itself which has a very wide expanse such as walking, talking, crying, working and so on. Behavior in preventing the occurrence of complications of hypertension in patients can be done by following the treatment program obediently and also limiting the consumption of foods that can worsen hypertension. Based on the results of the study, it was found that most of the respondents had behavior in the less category where this was due tothe perception of the patient himself where the patient assumes that hypertension will heal itself without having to be treated and is not a dangerous disease so there is no need to worry about the disease. In addition, it is also caused by low motivation to want to heal properly. Then also the lack of patient trust in health workers.

E. The Effect of Perception on Prevention Behavior of Complications of Hypertension at Raas Public Health Center, Sumenep Regency

Based on the results of Linear Regression analysis shows that the p-value is 0.008 $<0.05$ then $\mathrm{H} 1$ is accepted so it is concluded that partially there is the effect of perception on the behavior of preventing the occurrence of hypertension complications at the Raas Health Center, Sumenep Regency

Hypertension is a non-communicable disease that can become a big and serious problem because of the high prevalence of hypertension and tends to increase. In 2018 there was an increase in the prevalence of hypertension based on interviews (whether diagnosed by health workers and taking hypertension medication) from $7.6 \%$ in 2012 to 9.5 percent (Riskesdas, 2018).

The prevalence of hypertension mostly occurs in the elderly group, however, it turns out that the prevalence of hypertension in the productive age group tends to increase from year to year. According to the Ministry of Health of the Republic of 
Indonesia (2017) based on the results of the 2012 Basic Health Research (Riskesdas), most cases of hypertension in the community have not been diagnosed.

There are several factors that can increase a person's risk of suffering from hypertension. According to Sigarlaki (2016) the triggering factors for hypertension can be divided into 2 , namely factors that cannot be controlled (such as gender, genetics, and age) and factors that can be controlled (non-adherence to taking medication, lack of exercise, smoking, consumption of salt and excess fat). ).

This condition causes hypertension in the community as a silent killer or the silent killer, because hypertension generally occurs without any symptoms or is asymptomatic. Hypertension develops slowly, but is potentially very dangerous because it is a major risk factor for the development of heart disease and stroke (Dalimarta et al., 2013).

Because hypertension is a silent killer, the only way is to prevent and control hypertension. Efforts to prevent and control hypertension must begin by increasing public awareness and making changes to a healthier lifestyle. To understand and practice the right lifestyle and avoid disease, individuals and society need to learn proper behavior (Miller, 2014). In this case, the health belief model (HBM) is the first theory in the field of health related to health behavior. HBM can explain prevention behavior and individual response to disease.

The perspective or perception of a person will affect behavior both consciously and unconsciously. As with the behavior of preventing the occurrence of complications of hypertension, it can be influenced by the perception that this disease is not dangerous and the therapy is not important, many even believe in mystical treatment. Belief itself can influence behavior because basically someone will do something because someone believes it (Brenda, 2011).

According to researchers, the patient's perception of the dangers of hypertension is closely related to the patient's behavior in taking treatment. Where many patients consider hypertension to be harmless and believe more in traditional therapy, many even believe in spiritual treatment. This can increase the possibility of complications of hypertension to become other dangerous diseases such as stroke.

\section{F. The Effect of Motivation on Prevention Behavior of Complications of Hypertension at Raas Public Health Center, Sumenep Regency}

Based on the results of Linear Regression analysis shows that the p-value 0.000 $<0.05$ then $\mathrm{H} 0$ is rejected and $\mathrm{H} 1$ is accepted so it is concluded that partially there is the influence of motivation on the behavior of preventing complications of hypertension at the Raas Health Center, Sumenep Regency.

This is in accordance with the opinion of Supardi \& Anwar (2014) that a person is motivated by success, the hope of success is one's self-satisfaction, success will increase one's self-esteem and move one towards achieving goals. In addition, the marital status of respondents, most of whom are widowed, also affects their motivation in preventing complications and treating hypertension.

Motivation is anything that pushes someone to do something. Motivation is a change in a person's energy which is characterized by the emergence of "feeling" and is preceded by a response to the existence of a goal (Sardiman, 2012). Every action that motivates someone has a goal to be achieved. The clearer the goals that are expected or will be achieved, the clearer is how the motivating action is carried out. Motivating action will be more successful if the goal is clear. Therefore, everyone who will provide motivation to someone must really know and understand the life background, needs, and personality of the person to be motivated. 
There are two kinds of motivation, namely internal motivation and external motivation. Internal motivation is motivation that arises from within a person so that it affects thoughts and behavior to achieve goals while external motivation is motivation that arises from outside one's self. Internal motivation includes needs, interests and expectations. External motivation includes encouragement, environment, and rewards (Supardi \& Anwar, 2014).

According to researchers, the better the motivation of hypertension sufferers to be able to control the disease and prevent its complications, the lighter the degree of hypertension or the severity of the disease. Complications that can occur from hypertension are stroke, kidney failure, and heart disease. Patients with hypertension who have high motivation or drive to recover will try to comply with all doctor's recommendations, namely by regulating their diet, regular light exercise, regularly checking their blood pressure and also taking medication as recommended by the doctor.

\section{G. The Effect of Belief on Prevention Behavior of Complications of Hypertension at} Raas Health Center, Sumenep Regency

Based on the results of Linear Regression analysis shows that the p-value is 0.002 $<0.05$, then $\mathrm{H} 0$ is rejected and $\mathrm{H} 1$ is accepted, so it can be concluded that partially there is the effect of belief on behavior to prevent hypertension complications at the Raas Public Health Center, Sumenep Regency.

The results of this study are consistent with the results of previous studies which suggest that belief in the effectiveness of therapy is closely related to good blood pressure management (Kirscht \& Rosenstock, Nelson, et al., Ross, et al., in Heckler, et al., 2008).

Belief in the effectiveness of therapy is formed from the combination of information that provides pictures of the disease with the experiences experienced by patients during illness. Belief in the effectiveness of therapy is one of the five constructs of a personal model consisting of the patient's identity (which is a characteristic of a condition), experience of symptoms, consequences that must be accepted related to the disease suffered by the patient, duration of illness, and the patient's ability to control the disease. treatment and the effectiveness of the patient's treatment (Hagger \& Orbel, in Heckler, et al., 2013). This personal construct model is widely used to predict changes in patient behavior and identify barriers to health promotion efforts.

Research conducted by Shin, Yun, Pender and Jang (2015), shows that the selfconfidence variable on the effectiveness of therapy (the perceived benefit variable) has a relationship with self-efficacy and individual healthy behavior, meaning that belief in the effectiveness of therapy will be directly proportional to self-efficacy. . However, this contradicts the results of this study which showed that respondents had lower selfefficacy compared to self-confidence in the effectiveness of therapy. This shows that a high level of self-confidence in the effectiveness of therapy does not necessarily indicate a high respondent's self-efficacy state.

According to researchers, patients who are undergoing treatment therapy for diseases, especially hypertension, must have high confidence in the recommendations and information provided by health workers, where the benefits of these instructions are to reduce symptoms of hypertension and even cure the disease. However, in reality, many hypertensive patients do not believe in the information provided by health workers and underestimate their hypertension, which of course can cause hypertension to become uncontrolled and can worsen the patient's condition. 


\section{H. The Influence of Perception, Motivation and Belief on Behavior Prevention of Complications of Hypertension at Raas Public Health Center, Sumenep Regency}

Based on the results of Multiple Linear Regression analysis shows that with a pvalue of $0.000<0.05$ then $\mathrm{H} 1$ is accepted so it can be concluded that simultaneously there is the influence of perception, motivation and belief on the behavior of preventing the occurrence of complications of hypertension at the Raas Public Health Center, Sumenep Regency with a magnitude of $78.1 \%$.

Hypertension or high blood pressure is the most consistent risk factor for stroke from various previous studies. Hypertension or high blood pressure disease is a disorder in the blood vessels that causes the supply of oxygen and nutrients carried by the blood to be blocked to the body tissues that need it (Apriany, 2012). Hypertension is a risk factor for stroke that can increase the risk of stroke 2-4 times, independent of other risk factors. An increase in both systolic and diastolic pressure is associated with a higher risk. For every increase in diastolic blood pressure of $7.5 \mathrm{mmHg}$, the risk of stroke increases 2-fold. If hypertension can be controlled properly, the risk of stroke decreases by $28-38 \%$ (Nurrahmani, 2012).

In the study, Rico J. Sitorus et al (2015) found definitive hypertension, with systolic blood pressure 140 and diastolic $90 \mathrm{mmHg}$. With increasing age, hypertension is one of the most important modifiable risk factors for stroke. In this study, a history of hypertension had a significant effect on having a stroke at a young age. $(\mathrm{p}=0.001)$ with a risk level of 5.76 times compared to those without a history of hypertension.

While the research conducted by Husni A Laksmawati (2016) about the factors that influence the occurrence of non-hemorrhagic strokes again conducted at Dr. RSU. Karyadi Semarang got OR $=3.87$ in systolic blood pressure hypertension patients and 2.49 in diastolic blood pressure hypertension patients, this shows that hypertensive patients have a greater risk of recurrent stroke.

Meanwhile, in a study conducted by Friday et al (2012) with a cohort study design reported the incidence of recurrent stroke of 9.7\% among 535 patients with blood pressure follow-up. It was stated that patients with diastolic blood pressure $80 \mathrm{mmHg}$ had a 2.4 times greater risk of recurrent stroke compared to diastolic blood pressure $<80$ $\mathrm{mmHg}$, as well as patients with systolic blood pressure $140 \mathrm{mmHg}$ compared to systolic blood pressure $<140 \mathrm{mmHg}$.

According to Gunawan (2011), to avoid fatal complications of hypertension, it is necessary to take good preventive measures (stop high blood pressure) as follows: Reducing salt consumption, avoiding obesity (obesity), limiting fat consumption, exercising regularly, eating lots of fruit. and fresh vegetables, do not smoke and do not consume alcoholic beverages, do relaxation or meditation, and try to build a positive life.

According to researchers, the occurrence of complications due to hypertension can vary which can harm the sufferer's body, and can even cause death. Where the main cause of hypertension complications is the belief in the importance of health and behavior will obey the instructions of health workers. The wrong perception of the patient causes the patient to ignore everything related to hypertension. The extent to which patients are not motivated to recover from hypertension and consider the disease to be harmless. Even patients also do not believe in the treatment instructed by health workers to cure hypertension. 


\section{CONCLUSION}

1. Almost half of respondents have a perception of sufficient category as many as 47 respondents $(41 \%)$

2. Almost half of the respondents have a moderate category of motivation as many as 46 respondents $(40 \%)$

3. Almost half of the respondents have confidence in the medium category as many as 47 respondents (41\%).

4. Most respondents have behavior in the less category as many as 84 respondents (74\%)

5. There is an influence of perception on the behavior of preventing hypertension complications at the Raas Health Center, Sumenep Regency

6. There is the influence of motivation on the behavior of preventing complications of hypertension at the Raas Health Center, Sumenep Regency

7. There is the influence of trust on behavior to prevent hypertension complications at Raas Public Health Center, Sumenep Regency

8. There is an influence of perception, motivation and belief in the behavior of preventing hypertension complications at the Raas Health Center, Sumenep Regency

\section{SUGGESTION}

1. For Respondents

It is expected that hypertensive patients can obediently consume drugs given by health workers, which drugs should be consumed until they run out according to schedule and routinely control the previously used health facilities.

2. For Educational Institutions

It is hoped that educational institutions can use the results of this study as learning input in the application of the HBM (Health Belief Model) theory to the behavior of preventing hypertension complications at the Raas Health Center, Sumenep Regency and can be developed again for further research to be more useful for readers and for researchers.

3. For Further Researchers

It is hoped that further research needs to be deepened and added more specific research on factors that influence the behavior of preventing complications of hypertension at the Raas Health Center, Sumenep Regency

\section{ACKNOWLEDGMENT}

I solemnly declare that to the best of my knowledge, in this thesis there is no scientific work that has been submitted by another person to obtain an academic degree at a university, and there is no work or opinion that has been written or ordered by anyone. others, except those quoted in this manuscript and mentioned in the citation sources and bibliography.

\section{CONFLICT OF INTEREST}

In this study, there is no interest whatsoever regarding myself or with other institutions other than the Indonesian Strada Institute of Health Sciences, Kediri City.

\section{REFERENCES}

Adawiyah. (2014). Perception of the Elderly with Hypertension Prevention Efforts at Posbindu Bumi Asri RW IV, Sambiroto Village, Semarang. Semarang: Muhammadiyah University. Thesis

Indonesian Ministry of Health Research and Development Agency (2013). Jakarta: Basic Health Research (RISKESDAS).

Dalimarta, Purnama, Sutrisna, Mahendra, Darmawan (2013). Care Yourself. Hypertension. Jakarta: Spreader Plus

Ministry of Health Republic of Indonesia (2013). National Policies and Strategies for the Prevention and Management of Non-Communicable Diseases. Jakarta: The Indonesian Ministry of Health.

kemeMinistry of Health of the Republic of Indonesia (2012).httphttp://www.depkes.go.id

kemeMinistry of Health of the Republic of Indonesia (2013).httphttp://www.pptm.depkes.go.id

Kurniawati C, Sulistyowati M. (2014). Application of the Health Belief Model Theory in the 
Prevention of Pathological Leucorrhoea. Public Health Journal

Maes S, Karoly P. (2015). Self-Regulation assessment and intervention in physi- cal health and disability:Areview. Applied Psychology: An International Review, 54(2).

Miller MA, Stoeckel PR. (2011). 1st edn. Sudbury, Massachusetts, US: Jones and Bartlett. Client education theory and practice: 22 .

Mulyati L, Yetti K, Sukmarini L. (2013). Analysis of Factors Affecting Self Management Behavior in Hypertensive Patients. Jakarta: University of Indonesia. Thesis

Onoruoiza SI, Musa, Umar BD, Kunle (2015). Using Health Beliefs Model as an Intervention to Non Compliance with Hypertension Information among Hypertensive Patient. IOSR Journal Of Humanities And Social Science (IOSR-JHSS), 20(9): V

Purwono. J (2014). Factors Associated with Commitment to Prevention of Tertiary Hypertension in Communities in the Work Area of Metro City Health Center 2014. Journal of Nursing Aisyiyah 1 (2).

Robinson T (2012). Hypertension Beliefs And Behaviors Of African Americans In Selected Cleveland Public Housing. Kent State University College. Dissertation.

Rosenstock IM, Strecher VJ, BeckerMH (1988). Social Learning theory and health Belief Model.Health Education Quarterly,15(2).

Sarafino EP (2016). Health Psychology: Biopsychosocial Interactions. New York: John Wiley \& Sons, Inc.

Skinner TC, John M, Hampson SE (2010). Social support and personal models of diabetes as predictors of self care and well being: A longitudinal study of adolescents with diabetes. Journal of Pediatric Psychology, 25(4).

SigarlakiH (2011). Characteristics and Factors Associated with Hypertension in Bocor Village, Bulus Pesantren District, Kebumen Regency, Central Java. THEN 10 (2).

Sholiha M (2014). An Overview of Behavioral Change Opportunities with the Health Belief Model in Hypertensive Patients at the Ciputat Public Health Center, South Tangerang. Jakarta: Syarif Hidayatullah State Islamic University. Thesis.

Suhadi (2011). Analysis of Factors Affecting Elderly Compliance in Hypertension Treatment in Srondol Public Health Center, Semarang City. Jakarta: University of Indonesia. Thesis 